\title{
Assessment of Chlorpyrifos Pollution on Cichlidogyrus sp Infestation and the Oreochromis niloticus Immune Status
}

\author{
Zeinab M. El-Bouhy, Gamal El- Nobi A., Rasha M. Reda*, Rowida E. Ibrahim \\ Department of Fish Diseases and Management, Faculty of Veterinary Medicine, Zagazig University, Zagazig, Sharkia, Egypt
}

Email address:

rashareda55@yahoo.com (R. M. Reda),rmreda@zu.edu.eg (R. M. Reda)

${ }^{*}$ Corresponding author

\section{To cite this article:}

Zeinab M. El-Bouhy, Gamal El- Nobi A., Rasha M. Reda and Rowida E. Ibrahim. Assessment of Chlorpyrifos Pollution on Cichlidogyrus Sp Infestation and the Oreochromis niloticus Immune Status. International Journal of Ecotoxicology and Ecobiology

Vol. 2, No. 1, 2017, pp. 8-21. doi: 10.11648/j.ijee.20170201.12

Received: November 23, 2016; Accepted: December 7, 2016; Published: January 10, 2017

\begin{abstract}
One hundred and fifty O. niloticus $(35 \pm 0.5 \mathrm{~g})$ were collected from Abbassa Fish Hatchery, Sharkia, Egypt to determine the changes in immune parameters (after 15 and 30 days) of Oreochromis niloticus exposed to Organophosphrous insecticide (Chlorpyrifos) and infested with Cichlidogyrus $s p$. In addition, this study was carried out to evaluate the effect of the Chlorpyrifos exposure on the intensity and vitality of Cichlidogyrus sp. Chlorpyrifos decreased significantly both parasitic intensity and vitality. Serum total proteins, albumin and globulin were significantly decreased in both infested group and infested ones with pesticide exposure. Serum IgM level was elevated in infested group after 15 days of the experiment and decreased after 30 days of the experiment. Serum lysozyme and nitric oxide were elevated in all experimental groups after 15 and 30 days of the experiment. While phagocytic \% and Phagocytic index were significantly decreased in all experimental groups after 15 and 30 days of the experiment. The expression of IL-1 $\beta$ were significantly increased after 15 days of the experiment, while both infestation and Chlorpyrifos exposure showed no significant differences after 30 days. In conclusion, infection with Cichlidogyrus sp. in fish exposed to Chlorpyrifos pollution had the highest drastic effect on the health and immune status of fish.
\end{abstract}

Keywords: Chlorpyrifos, Oreochromis niloticus, Immune Response, Cichlidogyrus sp

\section{Introduction}

There are many biotic and abiotic stress factors affecting fish health condition. Parasites considered one of the important biotic stress factors affecting their hosts [1]. In Egypt, the studies of fish parasites become very important, because fish are playing a compensatory source of protein. The quality and palatability of fish reduced due to the presences of parasites. Fish gills are one of the biotope organs, which attacked by many fish ectoparasites [2]. Among these ectoparasite, the monogenetic trematodes, which cause severe destruction of the gills and severe economic losses [3]. Monogenetic trematodes are flatworms; mostly infest the gills, skin and fins of fishes and lower vertebrates. About 100 families of monogeneans found on fishes of the world, in fresh and salt water, and at a variety of temperatures [4].

Pesticide pollution considered one of the important abiotic stress factors affecting health of aquatic organisms. Organophosphate insecticides were produced and entered the environment in large amount than other pesticides; this is due to due to its rapid degradation in the environment the rapid degradation of these pesticides in the environment [5]. Organophosphate escape into water bodies as consequence of rain and leaching from the soil lead to pollution of water in which fish life [6]. Chlorpyrifos is an organophosphrous pesticide that is highly toxic and has a bad effect on the behavioral responses of fish [7].

In recent years, there is increasing awareness that fish parasites have been proposed as effective bioindicators for the environmental pollution [8,9]. Little information are available on the simultaneous effects of parasites and pollutants on the immune status of fish. Undoubtedly, that the infected fish would suffer more than uninfected one from 
environmental pollution because of their repair and detoxification systems are not working adequately [10]. Therefore, the aim of the present study is to investigate the effect of Chlorpyrifos pollution on the intensity and viability of parasites and to investigate the combined effects of Cichlidogyrus $s p$ and Chlorpyrifos pollution interact and their effect on immune status of the Oreochromis niloticus.

\section{Material and Methods}

\subsection{Experimental Design}

One hundred and fifty naturally infested Oreochromis niloticus were selected according to parasitological examination (Fish have sufficient number of monogenetic trematodes $=3-6$ parasite/ field). Fish $(35 \pm 0.05 \mathrm{~g})$ were obtained from Abbassa Fish Hatchery, Sharkia, Egypt. Fish specimens were kept in glass aquaria $(80 \times 40 \times 30 \mathrm{~cm})$ filled with $50 \mathrm{~L}$ of dechlorinated tap water and kept for two weeks for acclimation. Fish were allocated into five groups; each group had three replicates ( 10 fish replicate ${ }^{-1}$ ). The $\mathrm{LC}_{50}$ at 96 hrs of Chlorpyrifos was previously determined by El-Bouhy et al. [11]. Group1 (G1; control negative group) fish was non-infested, which were treated with Nacl 2 g/l with continuous water exchange to kill any monogenetic trematode infestation and non-exposed to pesticide. Group 2 (G2; control positive group) fish was infested with Cichlidogyrus sp without pesticide exposure. Group 3 (G3) were Cichlidogyrus sp infested fish exposed to $1 / 896 \mathrm{hrs}$ $\mathrm{LC}_{50}(0.008 \mathrm{mg} / \mathrm{l})$ of Chlorpyrifos. Group 4 (G4) were Cichlidogyrus sp infested fish exposed to $1 / 2096 \mathrm{hrs} \mathrm{LC}_{50}$ (0. $0035 \mathrm{mg} / 1)$ of Chlorpyrifos and group 5 (G5) were Cichlidogyrus sp infested fish exposed to $1 / 4396 \mathrm{hrsLC}_{50}$ $(0.0016 \mathrm{mg} / \mathrm{l})$ of Chlorpyrifos. The fish were fed on basal diet obtained from Fish Research Unit, Faculty of Veterinary Medicine, Zagazig University; diet was given two times daily. The mortality rate were recorded during the experimental period (30 days).

\subsection{Parasitological Examination}

Parasitological examination was carried once on the middle of the first week of the experiment and then were examined daily at other three week of the experiment. Gills were examined by naked eye then was separated and each was microscopically examined by compression technique at lower power magnification $(4 \mathrm{x})$. The intensity of ectoparasites was determined according to Bush et al. [12]. The vitality of parasites was reported based on a score system; score 1: parasite was inactivated and dead, Score 2: parasite was sluggish in movement and score 3: parasite was moderate in their vitality and movement. Finally, score 4: the parasite was with high vitality, where, Cichlidogyrus sp. appeared bobbing or stretching and compressing their body fast [13].

\subsection{Non-specific Immune Parameters}

Blood samples were obtained by puncturing the caudal blood vessels after 15 and 30 days of the experiment. The blood samples were collected without heparin for serum separation and were centrifuged at $3000 \mathrm{rpm}$ for $15 \mathrm{~min}$ then stored at $-20^{\circ} \mathrm{C}$ until analysis. Serum total protein, albumin and globulin levels were assayed [14-16]. Immunoglobulin M (IgM) was determined using ELISA Kit. Lysozyme activity, nitric oxide, phagocytic activity was determined according to Mohrig and Messner [17], Sun et al. [18] and Thompson [19].

\subsection{Expression of IL-1ß by Quantitative RT (Real Time)-PCR}

Total RNA was extracted from the spleen tissue after 15 and 30 days of the experiment using easy-REDTM following the manufacturer protocol (iNtRON Biotechnology, South Korea). The concentration and purity of the extracted RNA were determined via spectrophotometry using a Nano Drop. Complementary DNA was produced following the manufacturer's instructions of a Quantitect ${ }^{\circledR}$ Reverse Transcription kit (Qiagen, Germany). Quantitative real-time PCR analysis was performed with SYBR green PCR master mix (Step OnePlus, Applied Biosystem, USA). The target gene chosen was IL-1 $\beta$ (F: 5'TGCTGAGCACAGAATTCCAG-3'; R: 5'GCTGTGGAGAAGAACCAAGC-3'); as internal standard EF-1 $\alpha$ (F: 5'-CCTTCAACGCTCAGGTCATC-3'; R: 5'TGTGGGCAGTGTGGCAATC-3') [20, 21]. The following thermal cycling conditions were used for the exposed gene: initial denaturation at $94^{\circ} \mathrm{C}$ for $5 \mathrm{~min}, 40$ cycles of amplification (DNA denaturation at $94^{\circ} \mathrm{C}$ for $15 \mathrm{~s}$, annealing at $62^{\circ} \mathrm{C}$ for $30 \mathrm{~s}$, extension at $72^{\circ} \mathrm{C}$ for $30 \mathrm{~s}$ ). The final extension at $62^{\circ} \mathrm{C}$ for $1 \mathrm{~min}$.

\subsection{Statistical Analyses}

The data were analyzed by compare means differences using analysis of variance (One Way ANOVA). Two way ANOVA were used to determine the significant effect of the doses of Chlorpyrifos and time of exposure on intensity and vitality of Chichlidogyrus sp. A P- value of $\leq 0.05(\mathrm{P} \leq 0.05)$ was considered statistically significant. The data were analyzed using STATISTICA program (StatSoft, Inc., 2008, version 8).

\section{Results and Discussion}

\subsection{Mortality Rate}

The mortality rate of $O$. niloticus was the highest in G3 (infested and exposed to $1 / 896 \mathrm{hrs} \mathrm{LC}_{50}$ of Chlorpyrifos)

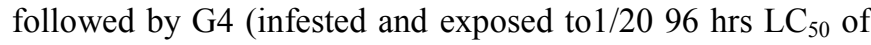
Chlorpyrifos) compared to control group (Fig. 1). This may be returned to the stress condition (the presence of parasite infestation and Chlorpyrifos pollution), which fish reared in it. This result agree with Chindah et al, [22] who founded that Tilapia guineensis exposed to sub lethal concentrations of Chlorpyrifos $(0.0125 ; 0.025 ; 0.05$ and $0.1 \mathrm{mg} / \mathrm{l})$ showed increase mortality with increase concentration level and exposure time. 


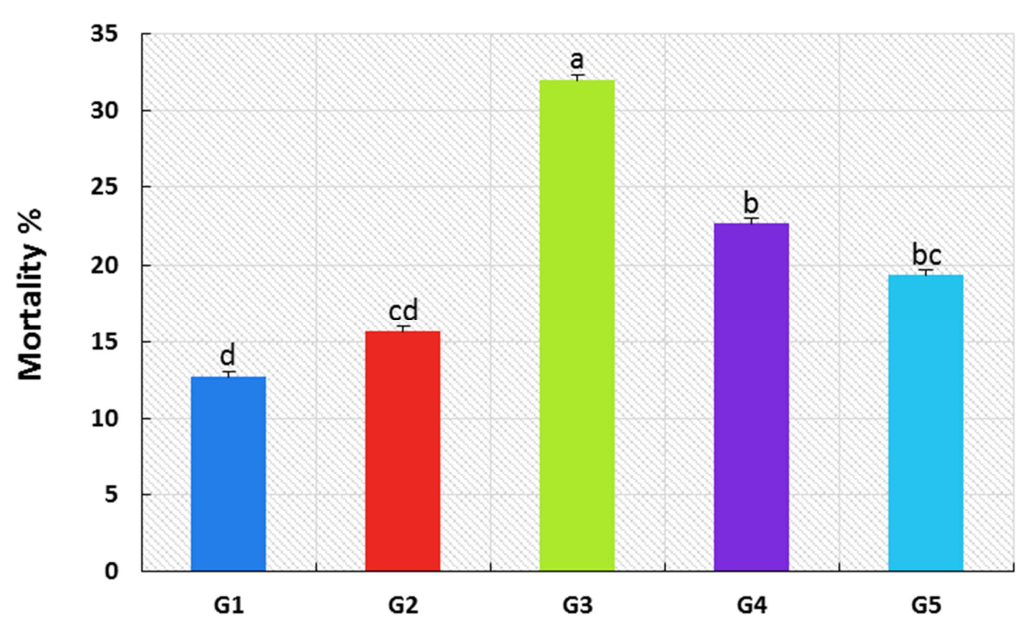

Fig. 1. The effect of different Chlorpyrifos concentrations on fish mortality rate at the end of experimental period (30 days). Bars with different superscripts (a, $b$ and c) are significantly different ( $P<0.05$, using a one-way ANOVA).

\subsection{Effect of Different Chlorpyrifos Concentrations on Cichlidogyrus sp Intensity and Vitality}

The Cichlidogyrus sp. intensity and vitality were decreased with the increase of Chlorpyrifos concentrations during the first nine days of the experiment. The significant decrease was recorded in G3 (infested fish and exposed to 1/8 $96 \mathrm{hrs}$ $\mathrm{LC}_{50}$ of Chlorpyrifos), which the average of intensity were $1.66 \pm 0.33,1.33 \pm 0.33$ and $0.66 \pm 0.33$ at 3,7 and 8 days of the experiment, respectively then followed by G4 and G5. While the highest of these groups was the second group (G2) (Cichlidogyrus $s p$ infested fish without pesticide exposure) with an intensity average $3.33 \pm 0.33, \quad 3.00 \pm 0.00$ and $1.66 \pm 0.33$ at 3,7 and 8 days of the experiment. At day 9 of the experiment, there were no significant differences between all experimental groups, after that the infestation disappear. Zaki et al. [23] mentioned that pesticides and heavy metals affect external parasite irreversibly. This may be attributed to the killing effect of Chlorpyrifos on the monogenea sp. [24].
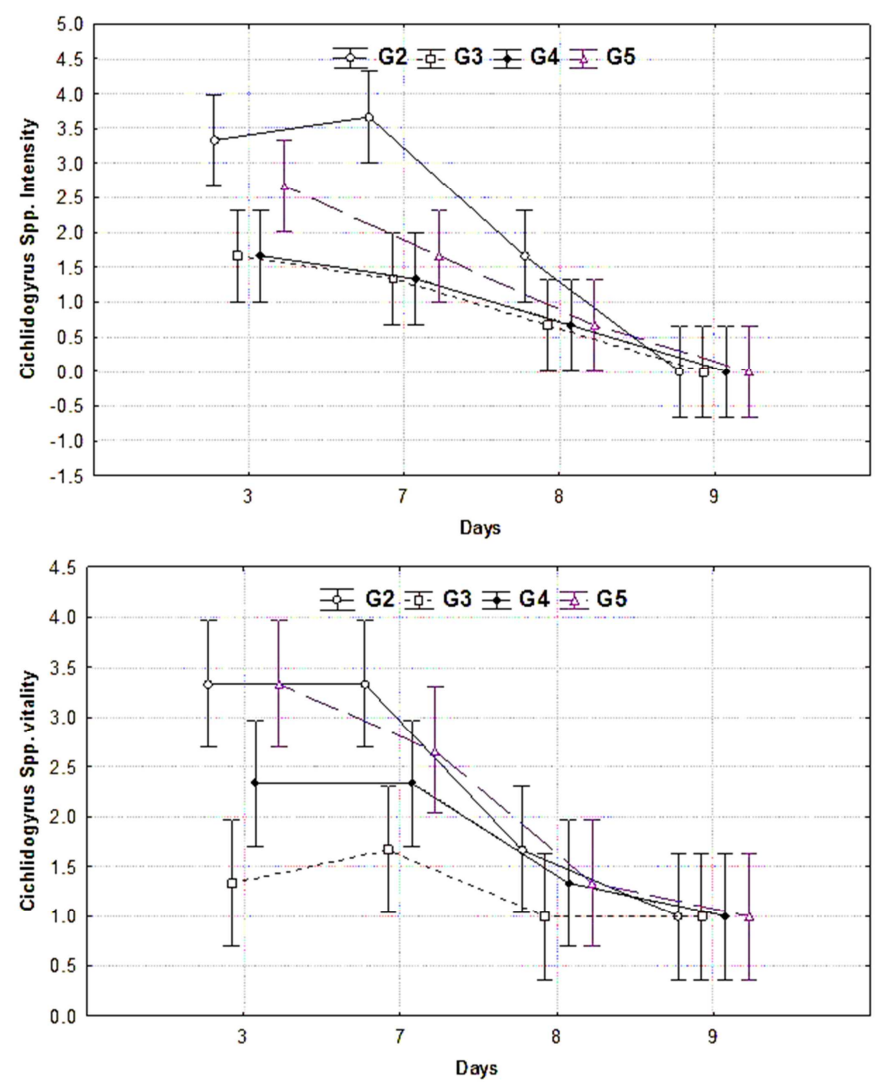

Fig. 2. The effects of the different concentrations of Chlorpyrifos and time of exposure on Cichlidogyrus sp. intensity and vitality. 


\subsection{Non-specific Immune Parameters}

The results of total proteins, albumin and globulin levels (Fig. 3) were recorded significant decreased in all experimental groups after 15 and 30 days of the experiment compared to control group (G1). Decreased total proteins, albumin and globulin in infested group (G2) may be attributed to stress condition caused by parasite, also some level of liver dysfunction under infestation condition. Infested gills lead to disturbance of osmoregulation, so the decrease in these parameters may be due to hemodilution [25]. Additionally, the decline in the total protein level may be due to the feeding habit of parasite that consumes the nutrient materials as supported by Eissa et al. [26]. This observation also agreed with Özdemir et al. [27] who reported the decrease in the total proteins and globulin in Bogue fish (Boops boops), which parasitized by the ectoparasite; Ceratothoa oestroides. While decrease of these parameters under both infestation and Chlorpyrifos could be attributed to stress caused by both parasite and Chlorpyrifos pollution. Stress condition caused by pesticide pollution resulted in catabolism of the proteins to provide energy by the fish to withstand these stress condition [28].
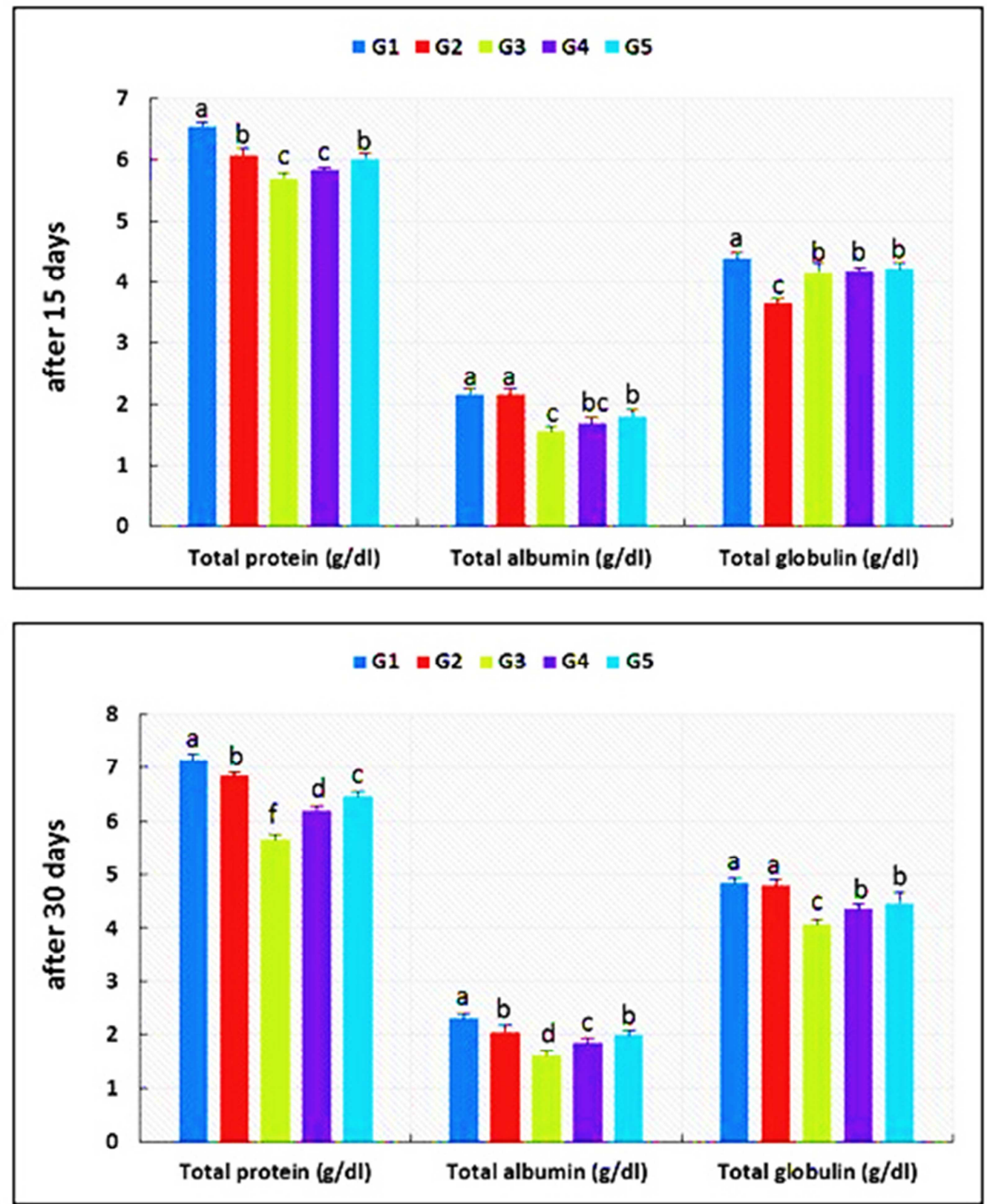

Fig. 3. Effects of the different concentrations of Chlorpyrifos on total serum protein $(\mathrm{g} / \mathrm{dl})$, albumin $(\mathrm{g} / \mathrm{dl})$ and globulin $(\mathrm{g} / \mathrm{dl})$ of Cichlidogyrus sp infested $\mathrm{O}$. niloticus after 15 days $(A)$ and 30 days $(B)$. The bars with different superscripts $(a, b$, and $c)$ are significantly different $(P<0.05$, one-way ANOVA). 
IgM level were significantly increased in G2 (infested with Cichlidogyrus $s p$ ) after 15 days and decreased after 30 days of the experiment (Fig. 4) where fish respond to gill monogeneans infestation by forming a specific immune response and then the level decreased after 30 days due to absence of the infestation. Similarly, Vladimirov [29] recorded an increase immunoglobulin production against Dactylogyrus vastator and D. extensus infection in carp. IgM specific antibodies was significantly increase in sera of tilapia infested with the Cichlidogyrus $s p$ and monogentic trematode as mentioned by Jaso-Friedmann et al. [30] and Abdel-Karim [31]. While IgM level decreased in all infested groups and exposed to Chlorpyrifos after 15 and 30 days of the experiment. The effect of Chlorpyrifos on the level of IgM was dominant than the infestation with Cichlidogyrus $s p$. The IgM level decrease was attributed to the inhibitory effect of Chlorpyrifos to immunity of fish as mentioned by Diaz-Resendiz and Giron-Perez [32] who recorded decrease in the plasma level of IgM in $O$. niloticus exposed to Chlorpyrifos $(0.051 \mathrm{mg} / \mathrm{mL})$.

Concerning, the level of lysozyme it was founded that, increase lysozyme in all experimental groups in compare to control group (G1) after 15 and 30 days of the experiment (Fig. 4). Lysozyme considered one of the non-specific molecules produced by fish against infestation, this explain increase lysozyme level in infested groups with Cichlidogyrus $s p$ as that recorded by Alvarez-Pellitero [33] who noticed change in the serum lysozyme levels in fish in response to parasite infestations.

In the similar manner, the nitric oxide was increased in all experimental groups in compare to control group (G1) after 15 and 30 days of the experiment (Fig. 5). Increase nitric oxide level in infested groups may be attributed to that; fish immune system respond to withstand the infestation, which nitric oxide are considered a very important molecule that involved in the regulation of various physiological and pathophysiological mechanisms in nervous and immunological systems [34]. The phagocytic \% and phagocytic index were decreased in all experimental groups compared with control (G1) after 15 and 30 days of the experiment (Fig. 5) where the Cichlidogyrus sp infestation and Chlorpyrifos pollution are considered as biotic and abiotic stress factors, which suppress the phagocytosis in fish. This result agree with that obtained by Lindenstrøm et al. [35] who reported that; phagocytosis by spleen and headkidney cells increased early after infestation, but later phagocytosis became depressed and parasite burdens decreased.
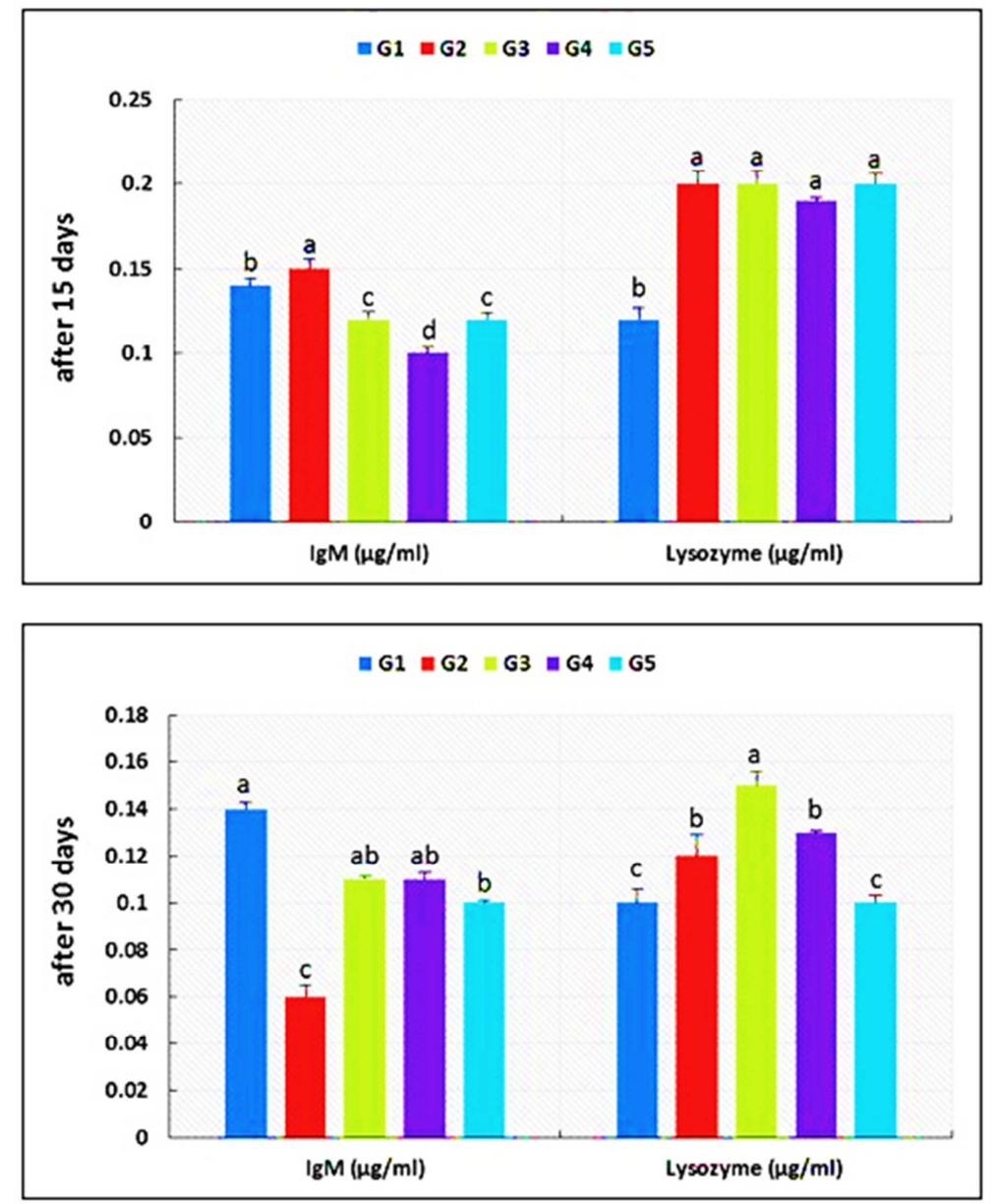

Fig. 4. The effect of the different concentrations of Chlorpyrifos on $\operatorname{IgM}(\mu \mathrm{g} / \mathrm{ml})$ and lysozyme activity $(\mu \mathrm{g} / \mathrm{ml})$ of Cichlidogyrus sp infested Oreochromis niloticus after 15 days $(A)$ and 30 days $(B)$. The bars with different superscripts $(a, b$, and $c)$ are significantly different $(P<0.05$, one-way ANOVA). 

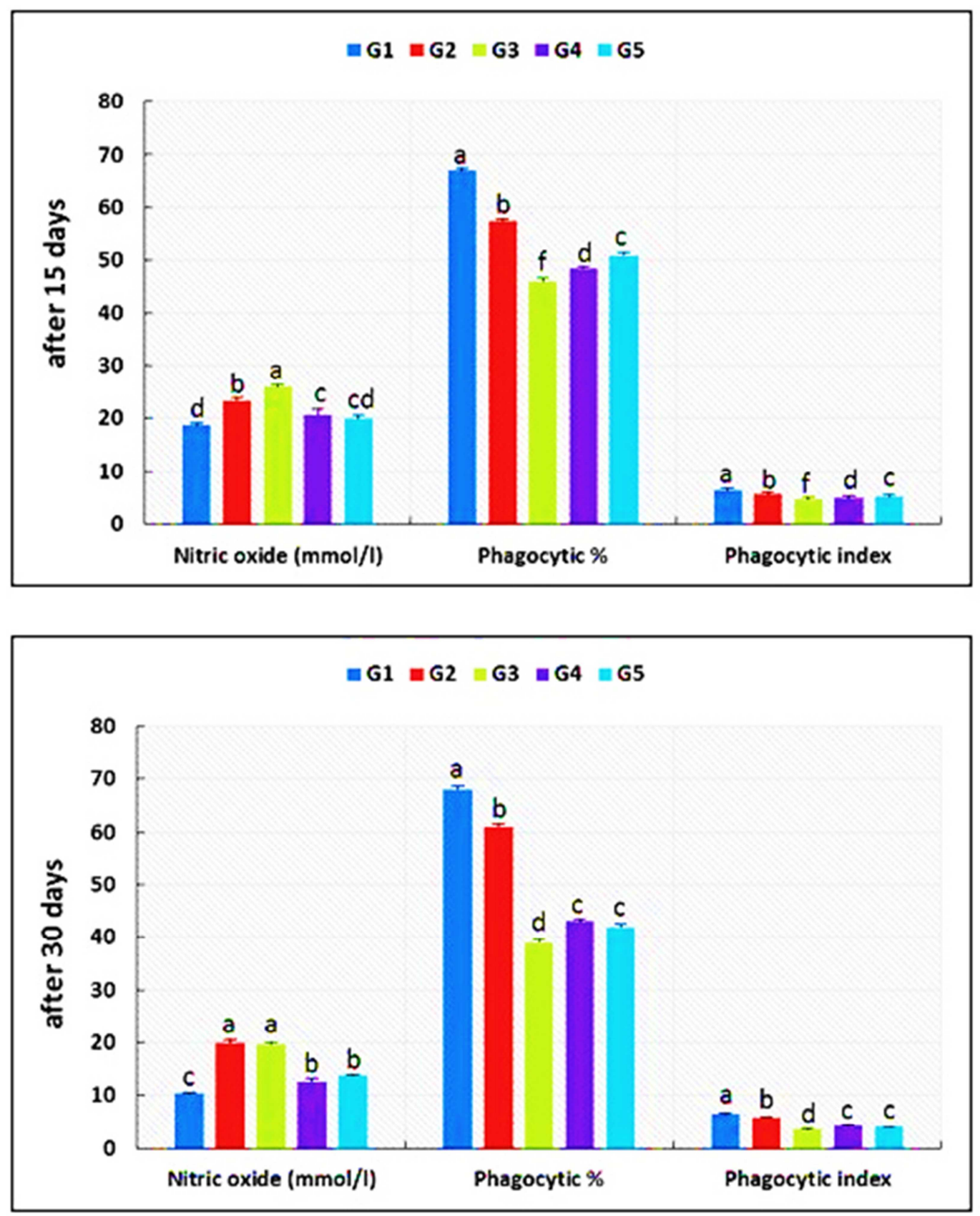

Fig. 5. Showing the effect of the different concentrations of Chlorpyrifos on nitric oxide (mmo/l), phagocytic \% and phagocytic index of Cichlidogyrus sp infested Oreochromis niloticus after 15 days $(A)$ and 30 days $(B)$. The bars with different superscripts $(a, b$, and $c)$ are significantly different $(P<0.05$, oneway ANOVA).

\subsection{IL-1ß Expression Gene}

The expression of IL-1 $\beta$ increased significantly in G2 followed by G3 than other experimental groups and control group (G1) after 15 days of the experiment. While, no significant differences between groups after 30 days of the experiment (Fig. 6). The infestation of $O$. niloticus with Cichlidogyrus $s p$ was stimulate the production of the pro inflammatory cytokines IL-1 $\beta$ as defense mechanism against the infestation. Lindenstrøm and Buchmann [36] reported that salmonids infested with Gyrodactylid respond initially to parasite invasion through discharging the contents of mucus cells and producing IL-1 $\beta$. Also, Lindenstrom et al [37] and
Lindenstrøm et al. [35] reported increase the expression of IL-1 $\beta$ after infestation by Gyrodactylus derjavini in rainbow and G. salaris in Atlantic salmon, respectively. The increase in the expression of IL-1 $\beta$ in Chlorpyrifos treated groups with infestation may be attributed to the immune response of fish to stress factor caused by pesticide pollution especially after 15 days of the experiment and returned to the normal level after 30 days of the experiment due to adaptation to the persisting stress condition. Wang et al. [38] reported an increase in the expression of mRNA of IL-1 $\beta$ of $C$. carpio that exposed to Chlorpyrifos $(1.16,11.6$ and $116 \mu \mathrm{g} / \mathrm{L})$ for 24 hrs. 


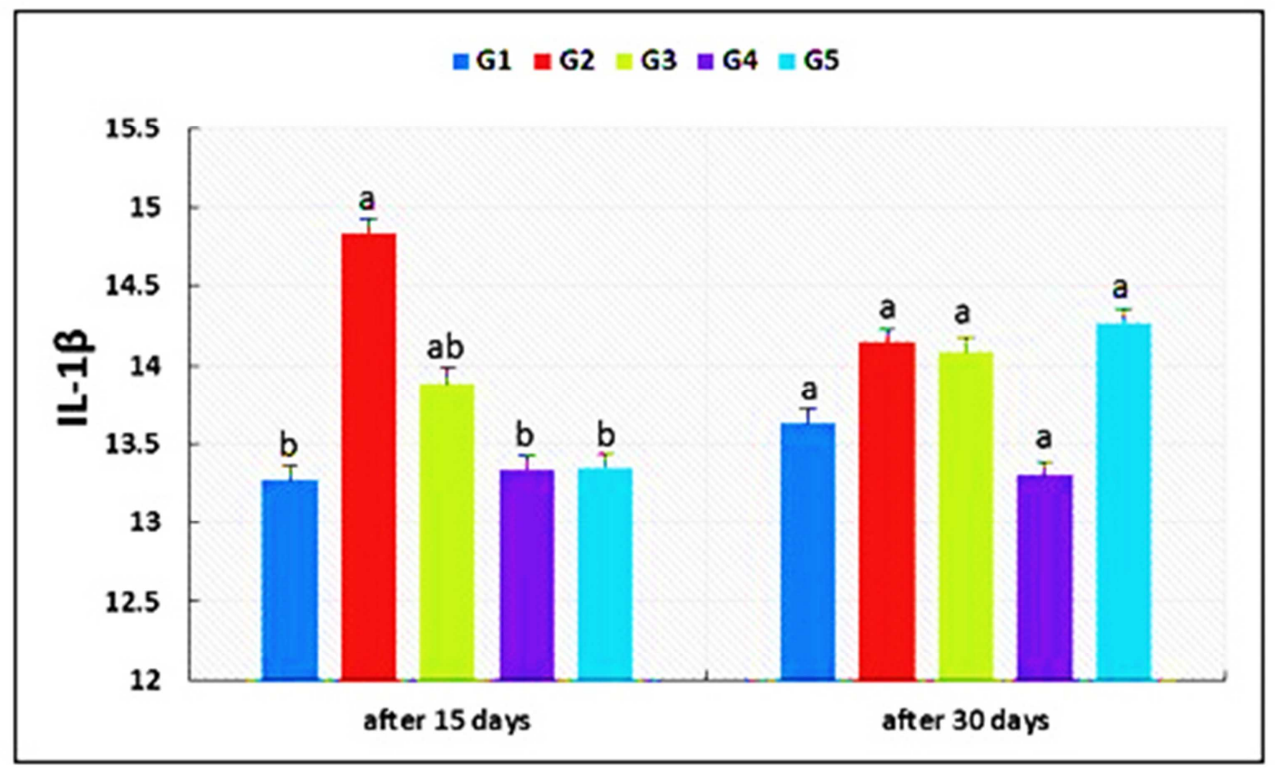

Fig. 6. The effect of the different concentrations of Chlorpyrifos on IL-1 $\beta$ gene expression of Cichlidogyrus sp infested Oreochromis niloticus after 15 days (A) and 30 days $(B)$. The bars with different superscripts $(a, b$, and $c)$ are significantly different $(P<0.05$, one-way ANOVA).

\section{Conclusion}

It can be concluded that, the conditions in which the fish are grown in terms of rearing in agricultural discharge water in addition to ectoparasitic infestation especially in intensive culture lead to high drastic effect on the immune system of fish, which adversely affect the yield of the fishery economy and a lack of productivity. However, further researches are needed in two main axes, first, how to treat the agricultural drainage water before used in fish farms. The second, by use new trends from immunostimulant in fish farms.

\section{References}

[1] Cheng, T. (1973): General ParasitologyAcademic Press. New York.

[2] Morsy, K. S.; Khalil, M. F.; Gamil, I. S.; Elebiarie, A. S. and Ibrahim, R. M. (2013): Heterobothrium lineatus (Monogenea: Diclidophoridae) infecting the gills of the Nile puffer Tetraodon lineatus (Pisces: Tetraodontidae) from the River Nile, Egypt with a new localit record: a light and scanning electron microscopic study. Journal of the Egyptian Society of Parasitology; 43:649-56.

[3] Morsy, K.; Saady, H.; Abdel-Ghaffar, F.; Bashtar, A. R.; Mehlhorn, H.; Al Quraishy, S. and Adel, A. (2012): A new species of the genus Heterobothrium (Monogenea: Diclidophoridae) parasitizing the gills of tiger puffer fish Tetraodon lineatus (Tetraodontidae). A light and scanning electron microscopic study. Parasitology research; 110:111924.

[4] Reed, P.; Francis-Floyd, R.; Klinger, R. and Petty, D. (2009): Monogenean parasites of fish. Fisheries and Aquatic Sciences University of Florida UF, IFAS Extension FA28, USA:1-4.
[5] Abo Nour, A. and Amer, A. (1995): Impairment of muscle performance in the Nile catfish Clarias lazera in response to hostathion insecticide contamination and/or gamma irradiation. J Egypt Ger Soc Zool; 18:153-75.

[6] Danasoury M. A. K. (1997): Effect of Malathion and Fentrothion on Na+- K+ ATPase Activity of Gills and Some Cations in Serum and Tissues of Nile Tilapia (Oreochromis nilaticus). Egypt J ZooL 28: 23-33.

[7] Rao, P.; Babu, N. B. and Raju, R. R. (2010): Study the effect of chlorpyrifos on proteins in fresh water fish Labeo rohita by using HPLC method. International Journal of Research in Pharmaceutical and Biomedical Sciences; 1:1-5.

[8] MacKenzie, K.; Williams, H.; Williams, B.; McVicar, A. and Siddall, R. (1995): Parasites as indicators of water quality and the potential use of helminth transmission in marine pollution studies. Advances in parasitology; 35:85-144.

[9] Lafferty, K. D.; Porter, J. W. and Ford, S. E. (2004): Are diseases increasing in the ocean? Annual Review of Ecology, Evolution, and Systematics: 31-54.

[10] Sures, B. (2008): Environmental parasitology. Interactions between parasites and pollutants in the aquatic environment. Parasite; 15:434-8.

[11] El-Bouhy Z. M.; El-Nobi, G. A.; Reda, R. M. and Ibrahim, R. E. (2016): Effect of pesticide "Chlorpyrifos" on immune response of Oreochromis niloticus. Zagazig Veterinary Journal; 44: in press.

[12] Bush, A. O.; Lafferty, K. D.; Lotz, J. M. and Shostak, A. W. (1997): Parasitology meets ecology on its own terms: Margolis et al. revisited. The Journal of parasitology: 575-83.

[13] Noga, E. (1996): Fish Diseases. Diagnosis and Treatment. St. Louis: Mosby-Year Book. Inc 367p.

[14] Gornall, A. G.; Bardawill, C. J. and David, M. M. (1949): Determination of serum proteins by means of the biuret reaction. J biol Chem; 177:751-66. 
[15] Weichselbaum, T. (1946): An accurate and rapid method for the determination of proteins in small amounts of blood serum and plasma. American journal of clinical pathology; 10:40.

[16] Dumas, B.; Watson, W. and Biggs, H. (1971): Quantitative colorimetric determination of albumin in serum or plasma. Clin Chem Acta; 31:87-91.

[17] Mohrig, W. V. and Messner, B. (1968): Immunreaktionen bei Insekten. I. Lysozym als grundlegender antibakterieller Faktor im humoralen Abwehrsystem der Insekten Biol Zbl;4:439-70.

[18] Sun, J.; Zhang, X.; Broderick, M. and Fein, H. (2003): Measurement of nitric oxide production in biological systems by using Griess reaction assay. Sensors; 3:276-84.

[19] Thompson, R. A. (1977): Techniques in clinical immunology: Blackwell Scientific Publications, Osney Mead, Oxford OX2 0EL.

[20] Pirarat, N.; Pinpimai, K.; Endo, M.; Katagiri, T.; Ponpornpisit, A.; Chansue, N. and Maita, M. (2011): Modulation of intestinal morphology and immunity in nile tilapia (Oreochromis niloticus) by Lactobacillus rhamnosus GG. Research in veterinary science; 91:e92-e7.

[21] Gröner, F.; Ziková, A. and Kloas, W. (2015): Effects of the pharmaceuticals diclofenac and metoprolol on gene expression levels of enzymes of biotransformation, excretion pathways and estrogenicity in primary hepatocytes of Nile tilapia (Oreochromis niloticus). Comparative Biochemistry and Physiology Part C: Toxicology \& Pharmacology; 167:517.

[22] Chindah, A.; Sikoki, F. and Ijeoma, V. A. (2004): Toxicity of an organophosphate pesticide (chloropyrifos) on a common Niger Delta Wetland fish-Tilapia guineensis (Blecker 1862).

[23] Zaki, S.; Shalaby, S.; Nagwa, A.; El-Deen, A.; Omar, S. and Abdelzaher, M. F. (2013): Effect of Aquatic Pollution on Fish (Review). Life Science Journal-Acta Zhengzhou University Overseas Edition; 10:637-42.

[24] De Lara Rodrigues, E.; Ranzani-Paiva, M. J. T. and Juliano, F. (2001): Histopathologic lesions in the liver of Prochilodus lineatus (Pisces, Prochilodontidae) exposed to a sublethal concentration of the organophosphate insecticide Dipterex 500® (Trichlorfon). Acta Scientiarum Maringá; 23:503-5.

[25] Osman, H.; Ismaiel, M. M.; Abbas, T. and Ibrahim, T. B. (2009): An approach to the interaction between Trichodiniasis and pollution with Benzo-apyrene in catfish (Clarias gariepinus). Fish Mar Sci; 1:283-9.

[26] Eissa, I.; Zaki, V.; Nadia, G. and Zaki, M. (2012): Studies on prevailing cestodiasis in wild African catfish Clarias gariepinus at Kafr El-Sheikh governorate. Life Science Journal; 9.
[27] Özdemir, G. C.; Celik, E. S.; Yılmaz, S.; Gürkan, M. and Kaya, H. (2016): Histopathology and blood parameters of Bogue fish (Boops boops, Linnaeus 1758) parasitized by Ceratothoa oestroides (Isopoda: Cymothoidae). Turk J Fish Aquat Sci; 16:579-90.

[28] Jenkins, F.; Smith, J.; Rajanna, B.; Shameem, U.; Umadevi, K.; Sandhya, V. and Madhavi, R. (2003): Effect of sub-lethal concentrations of endosulfan on hematological and serum biochemical parameters in the carp Cyprinus carpio. Bulletin of environmental contamination and toxicology; 70:0993-7.

[29] Vladimirov, V. (1971): Immunity of fish against Dactylogyrus. Parazitologiya; 5:51-8, 8 p.

[30] Jaso-Friedmann, L.; Ruiz, J.; Bishop, G. and Evans, D. (2000): Regulation of innate immunity in tilapia: activation of nonspecific cytotoxic cells by cytokine-like factors. Developmental \& Comparative Immunology; 24:25-36.

[31] Abd El-Karim, S. (2012): Studies on The effect of some antibiotics and disinfectant used for control of fish diseases in Nile tilapia (Oreochromis niloticus). M. V. Sc. Thesis, Faculty of Vet. Med. Zag. Univ.

[32] Díaz-Resendiz, K. and Girón-Pérez, M. (2014): Effect of chlorpyrifos on the immune response of Nile tilapia (Oreochromis niloticus). Efecto de clorpirifos sobre la respuesta inmune de Tilapia nilótica (Oreochromis niloticus). Revista Bio ciencias; 3:59-64.

[33] Alvarez-Pellitero, P. (2008): Fish immunity and parasite infections: from innate immunity to immunoprophylactic prospects. Veterinary immunology and immunopathology; 126:171-98.

[34] Szabó, C. (1996): Physiological and pathophysiological roles of nitric oxide in the central nervous system. Brain research bulletin; 41:131-41.

[35] Lindenstrøm, T.; Sigh, J.; Dalgaard, M. and Buchmann, K. (2006): Skin expression of IL - $1 \beta$ in East Atlantic salmon, Salmo salar L., highly susceptible to Gyrodactylus salaris infection is enhanced compared to a low susceptibility Baltic stock. Journal of Fish Diseases; 29:123-8.

[36] Lindenstrøm, T. and Buchmann, K. (2000): Acquired resistance in rainbow trout against Gyrodactylus derjavini. Journal of helminthology; 74:155-60.

[37] Lindenstrøm, T.; Buchmann, K. and Secombes, C. (2003): Gyrodactylus derjavini infection elicits IL-1 $\beta$ expression in rainbow trout skin. Fish \& shellfish immunology; 15:107-15.

[38] Wang, X.; Xing, H.; Li, X.; Xu, S. and Wang, X. (2011): Effects of atrazine and chlorpyrifos on the mRNA levels of IL- 1 and IFN- $\gamma 2 b$ in immune organs of common carp. Fish \& shellfish immunology; 31:126-33. 